\title{
KETIKA ALLAH "DIAM”: ANALISIS RETORIKA AYUB 39:4-15
}

\author{
Arif Wicaksono \\ Sekolah Tinggi Teologi Tawangmangu \\ Tromol Pos 1, Kalisoro, Tawangmangu, Karanganyar, Jateng \\ Email: arifsmille210299@gmail.com
}

\begin{abstract}
Arif Wicaksono, When God Is "Silent": Analysis of Rhetoric Job 39: 4-15. While referring to the contemplation of life's struggles, the book of Job is often one of the best stories in strengthening the faith of the congregation. Unfortunately, some approaches to the strengthening of faith in the book of Job take only in the first and second chapters, then immediately look at the last chapter of this book. It is rare to find the discussions touching the dialogs contained in the middle of this book. But if we want to look closely, the dialogues between Job and his friends, Job with God and God's answer to Job give a lot of life values about how believers should behave in temptation. This paper has a purpose to present one the topic of contemplation drawn from the dialogue between God and Job when God posed rhetorical questions to Job. The approach used in studying texts is a literal context approach with the aim of exploring the meaning of every word in Hebrew and the context that influences the text. What is to be expected in this discussion is that the reader can understand God's providence for the temptations his people experience in the rhetorical question raised to Job.
\end{abstract}

Keywords: Temptation, Providence, Rhetoric

\begin{abstract}
Abstrak: Arif Wicaksono, Ketika Allah Diam: Analisis Retorika Ayub 39:4-15. Saat memberikan rujukan perenungan terhadap pergumulan hidup, sering kali kitab Ayub dijadikan salah satu kisah terbaik dalam menguatkan iman jemaat. Sayangnya beberapa pendekatan terhadap penguatan iman dari kitab Ayub hanya mengambil dalam pasal pertama dan kedua kemudian meloncat pada pasal terakhir dari kitab ini. Jarang sekali pembahasan-pembahasan menyentuh dialog-dialog yang terdapat dalam bagian tengah dari kitab Ayub.Padahal jika mau melihat dengan baik dialog-dialog antara Ayub dan teman-temanya, Ayub dengan Tuhan dan jawaban Tuhan kepada Ayub memberikan banyak sekali nilai-nilai kehidupan tentang bagaimana seyogyanya orang percaya bersikap dalam pencobaan.Tulisan ini memiliki tujuan untuk megetengahkan salah satu topic perenungan yang terambil dari dialog antara Allah dengan Ayub saat Allah mengajukan pertanyaan-pertanyaan retorik kepada Ayub. Pendekatan yang dipakai dalam menelaah teks menggunakan pendekatan literal konteks, dengan tujuan menggali makna dari setiap kata dalam bahasa Ibrani dan konteks yang mempengaruhi teks.Diharapkan dalam pembahasan ini pembaca dapat memahami pemeliharaan Allah atas pencobaan yang dialami umat-Nya dalam pertanyaan retorik yang disampaikan kepada Ayub.
\end{abstract}

Kata Kunci: Pencobaan, Pemeliharaan, Retorik

\section{PENDAHULUAN}

Sebagai mahkluk hidup semua orang pasti pernah mengalami berbagai musim kehidupan. Ada saat untuk gembira ada saat untuk berduka. Ada saat bahagia tapi ada juga saat menderita. Kadangkala semuanya itu akan datang silih berganti tanpa bisa dicegah atau dihindari. Semua itu akan mendatangi orang kaya maupun orang miskin, orang kota atau orang desa, bahkan tanpa membedakan antara orang saleh maupun orang berdosa. Penderitaan merupakan suatu realitas yang tak terelakkan dan terus-menerus menghantui hidup manusia. Berbicara menge- nai penderitaan, kalau bisa memilih, kebanyakan orang akan berharap hal itu tidak akan terjadi dalam kehidupannya. Tapi disadari atau tidak, penderitaan bisa saja datang dengan begitu tiba-tiba tanpa mempedulikan kesiapan dari orang yang mengalami. Penderitaan dapat muncul dari penyakit, kematian orang dikasihi, kebangkrutan dan masih banyak hal lain yang bisa didaftarkan. Hal itu sangat tidak mengenakkan. Tidak seorang pun berharap penderitaan datang kepadanya.

Kitab Ayub, memaparkan suatu pertiwa yang akan membawa pembaca melihat bagaimana 
penderitaan itu menyerang bukan hanya orang yang jahat tetapi juga orang benar dan saleh. Penderitaan yang terjadi dalam kehidupan Ayub berlangsung secara bertubi-tubi, dalam waktu yang sangat singkat, sekalipun pada awalnya dia dinyatakan saleh dan benar. Tentu hal ini membawa pertanyaan yang besar dalam diri Ayub. Kesalahan apa yang telah ia perbuat sehingga penderitaan yang begitu hebat harus dia tanggung.

Ketika penderitaan yang hebat yang menimpa diri Ayub, ia melakukan setidaknya empat protes atas apa yang dialami. Protes pertama adalah keluhannya terhadap apa yang dialaminya, kedua adalah protes Ayub kepada teman-temanya tentang apa yang Allah lakukan, yang ketiga adalah protes Ayub kepada teman-temanya yang tidak menghibur tetapi justru memojokannnya, dan terakhir adalah protes Ayub langsung kepada Allah atas apa yang dialaminya.

Penderitaan yang dialami Ayub mendorongnya memberanikan diri untuk membela perkaranya dihadapan Tuhan (Ayb. 13). Keyakinan akan kesalehannya menjadikan dia percaya bahwa dia tidak pantas mendapatkan penderitaan (Ayb. 13: 22-24). Ayub merasa ketidakadilan terjadi kepadanya, dan Allah berdiam diri atas apa yang dia alami. Pada Ayub pasal 38-42, setelah perdebatan panjang antara Ayub dan teman-temannya, di sini Allah mulai menjawab perkara Ayub. Ayub disadarkan dengan setiap pertanyaan retorika yang Allah ajukan kepadanya. Ayub 39: 4-15 merupakan bagian dari jawaban Allah kepada Ayub, yang akan dibahas secara mendalam dalam penulisan jurnal ini.

Penelitian yang relevan dengan penelitian ini adalah penelitian yang dilakukan oleh Kalis Stevanus (2018). Penelitian Stevanus merupakan penelitian analisis pertanyaan retorika dalam Ayub 40:128. Penelitian Stevanus lebih mengedepankan usaha mencari implikasi teologis dan praktis dari analisis Ayub 40:1-28. Yang serupa dengan penelitian ini berusaha untuk menyajikan hasil analisis terhadap Ayub 39:4-15 dan akhirnya memaparkan implikasinya baik secara teologis maupun praktis. Perbedaan penelitian ini dengan penelitian Stevanus adalah perbedaan pasal dan ayat. Penelitian lain yang relevan dengan penelitian ini adalah penelitian yang dilakukan oleh Tolanda dan Maiaweng (2011). Hanya penelitian Tolanda dan Maiaweng lebih menyoroti tentang kedaulatan Allah atas iblis berdasarkan kitab Ayub pasal 1 dan 2 kemudian mengemukakan relevansinya dalam kehidupan orang percaya. Kedua penelitian tersebut merupakan penelitian yang telah terpublikasi pada jurnal dan relevan dengan penelitian ini.

\section{METODE}

Metode yang digunakan dalam pembahasan Ayub 39: 4-15 adalah deskriptif-analitis. Metode deskriptif adalah metode yang bersifat menjelaskan, menuturkan masalah dengan apa adanya dengan evidensi atau pendapat yang memadai. Metode analitis adalah metode yang memeriksa teks dan menjelaskan dengan menganalitis dan merumuskan gramatikal sehingga makna struktur dapat diyatakan secara tepat (Subagyo, 2004, p. 62). Jadi metode deskriptifanalisis yang dimaksudkan dalam penelitian ini adalah metode yang bersifat menjelaskan, menuturkan nats Ayub 39: 4-15 secara terperinci, dengan memeriksa menganalisis dan merumuskan struktur gramatikal sehingga makna Ayub 39: 4-15 dapat dinyatakan dengan tepat, dan selanjutnya dapat diimplementasikansecara spesifik dalam konseling Kristen dan pengajaran kristen.

Analisis yang digunakan dalam penelitian ini adalah menggunakan tafsirkritik literer. Kritik literer menempatkan teks sebagai sasaran akhir penggalian. Di sini teks diterima sebagaimana adanya, sedangkan berbagai soal yang berkaitan dengan sejarah perkembangan teks sengaja diabaikan sekalipun tidak sepenuhnya (Maryono, 2017, p. 7). Alasan pemilihan kritik literer adalah ciri dari kritik literer adalah perhatian cermat terhadap bahasa. Bahasa, lebih dari sekedar simbol/ lambang tetapi merupakan wujud komunikasi yang melibatkan sejumlah dinamika. Dalam prosedur penarikan kesimpulan, penulis melakukan penalaran induktif berdasarkan anali- 
sis data. Menurut Subagyo penalaran induktif adalah menarik kesimpulan logis melalui analisis data (Subagyo, 2004).

\section{HASIL DAN PEMBAHASAN}

\section{Latar Belakang Teks Ayub 39: 4-15}

Kitab Ayub merupakan salah satu kitab Perjanjian Lama yang mengandung banyak pertanyaan yang belum terjawab hingga saat ini. Tidak ada seorang pun yang mengetahui secara pasti penulis dari kitab ini. Diperkirakan kitab ini telah dikenal oleh Abraham saat dia berada di tanah Ur-Kasdim. Ada juga yang berpendapat bahwa kitab Ayub kemungkinan didapatkan oleh Musa pada saat pelariannya di Midian. Beberapa saran telah dikemukakan mengenai penulis kitab Ayub, mulai dari: Ayub, Elihu, Musa, Salomo, Yesaya, Hizki, Barukh teman dari Yeremia dan sebagainya. Namun dari semua yang disebutkan tidak satupun yang dapat dinyatakan dengan pasti.

Ketidakpastian juga ditemukan dalam penanggalan kitab Ayub. Tidak ditemukan rujukan-rujukan yang menunjuk peristiwa-peristiwa historis yang menolong dalam penanggalan kitab. Baker (1992, p. 91) menjelaskan bahwa Ayub hidup pada masa nenek moyang Israel (Abraham, Ishak dan Yakub). Para penulis LXX asli merasakan bahwa teks kitab Ayub sulit dipahami sehingga hampir seperempat kitab hilang. Terdapat beberapa perikop dalam teks purba yang tidak dapat diterjemahkan, sebagaimana dijelaskan dalam teks Massoretik (Davidson, 2006, p. 68).

Kitab Ayub digolongkan sebagai kitab hikmat. Hikmat diperoleh dari dua sumber utama yaitu pengalaman dan pemikiran. Hikmat pada waktu itu muncul bukan dari buku dan sekolah. Setiap orang, walaupun tidak berpendidikan, memperoleh hikmat dari pengalaman hidup sehari-hari dan sering hikmat itu dinyatakan dalam bentuk peribahasa atau perumpamaan (Baker, 1992, p. 91). Hikmat itu bersifat praktis, mengenai apa saja yang pelu diketahui untuk hidup sehari-hari.
Secara garis besar kitab ini terbagi menjadi tiga bagian. Bagian pertama adalah dilema Ayub. Pada bagian ini diceritakan tentang latar belakang Ayub dan setiap penderitaan yang menimpa Ayub. Bagian kedua adalah perdebatan. Bagian ini menceritakan perdebatan Ayub dengan keempat sahabatnya yang datang mengunjunginya. Bagian ketiga adalah pemulihan. Bagian ini bermula dari Ayub pasal 38 sampai dengan 42. Di sini diceritakan mengenai jawaban Tuhan atas apa yang Ayub alami dan ditutup dengan pertobatan Ayub sendiri. Pada bagian terakhir ini Allah sendiri, yang menegur ketidaktahuan dan keluhan Ayub serta mendengarkan tanggapan Ayub atas penyataan-Nya. Dalam pasal 38-42 Tuhan mengajar Ayub tentang ciptaannya jauh lebih besar dari dia (Harlow, 1983, p. 59). Tolanda \& Maiaweng (2011, p. 54) menjelaskan bahwa

Permulaan kitab Ayub diawali dengan perkenalan kepada seseorang yang bernama Ayub. Perkenalan ini dititik beratkan pada sifat dan karakter Ayub sebagai seorang yang saleh, jujur, takut akan Allah dan menjauhi kejahatan.

Pembahasan yang akan dibawakan penulis pada saat ini adalah mengenai "Pertanyaan Retorika Dalam Ayub 39: 4-15." Bagian ini merupakan percakapan antara Ayub dan Allah menjelang pemulihan keadaan Ayub. Ketika Allah menjawab segala keluh kesah Ayub dengan memberikan beragam pertanyaan retorika. Setiap pertanyaan retorika yang diajukan Allah kepada Ayub memiliki makna teologi yang mendalam untuk menjelaskan bagaimana seharusnya sikap orang percaya dalam menghadapi ujian yang datang. Walaupun setiap pertanyaan Allah tidak menjawab secara langsung terhadap pertanyaanpertanyaan Ayub, namun semuanya membawa perenungan yang mendalam untuk Ayub untuk mengenal Allah lebih mendalam, melebihi pengalaman pengetahuan yang telah ia miliki selama ini. Di sini Ayub mendapatkan pemahaman yang lebih mendalam dibanding dengan apa yang dimilikinya sebelumnya.

\section{Analisis Teks Ayub 39:4-15}

Setiap pertanyaan retorika yang Allah ajukan kepada Ayub semuanya berkenaan mengenai 
hewan-hewan yang luar biasa. Sepertinya semua hewan yang sebutkan dalam pembicara dikenal oleh Ayub. Akan sangat mustahil jika Allah harus membicarakan hewan yang tidak dikenal oleh Ayub, untuk menunjukan kebesaran-Nya atas alam semesta. Meskipun Ayubmemiliki pengetahuan atas hewanhewan tersebut, namun demikian Ayub memiliki keterbatasan pengetahuan dan kuasa atas setiap hewanhewan tersebut. Allah menunjukan bahwa Ia memiliki kuasa dan pemeliharaan yang sempurna terhadap hewan-hewan tersebut. Pertanyaan-pertanyaan yang diajukan Tuhan menjadi sangat menarik, mengingat semuanya membawa kesadaran dalam diri Ayub akan kebesaran Tuhan dan keterbatasan dirinya dihadapan Tuhan.

\section{Analisis Teks Ayub 39:4-5}

Dalam Ayub 39:4-5 dituliskan "Apakah engkau mengetahui waktunya kambing gunung beranak, atau mengamat-amati rusa waktu sakit beranak? Dapatkah engkau menghitung berapa lamanya sampai genap bulannya, dan mengetahui waktunya beranak?" Istilah Ibrani kata gunung dalam ayat tersebut יעל יעל (yâa'êl) "gunung karang, pegunungan cadas." Mereka tinggal di bukit gunung yang tinggi; Mazmur 104:18 menyebutkan bahwa. "Gunung-gunung yang tinggi adalah tempat berlindung bagi kambing liar."

Mengenai reproduksi anak kambing gunung, manusia sama sekali tidak tahu kapan mereka melahirkan (ay. 4-5). Tidak seorangpun mengerti dan dapat mengatakan dengan pasti mengenai takdir dari apa yang ada di dalam rahim kambing gunung. Tidak ada yang bisa menghitung secara pasti berapa lama kambing hamil, berapa genap bulannya, atau menentukan hari kapandia akan melahirkan? Sejak masa kehamilan sampai dengan kegenapan hari kelahiran anak kambing hanya Allah yang tahu semuanya itu.

Meskipun kambing-kambing melahirkan anak-anak mereka dengan banyak kesulitan dan kesedihan, dan tidak mendapatkan bantuan dari manusia, namun, dengan pemeliharaan Tuhan, anak-anak mereka dilahirkan dengan aman. Poin khusus dalam penyelidikan di sini tidaklah berkenaan dengan bagaimana hewan-hewan ini melahirkan anak-anak mereka, yang mungkin diketahui oleh manusia, namun berkaitan dengan perhatian dan pemeliharaan yang mereka butuhkan saat mereka hendak melahirkan. Kambing-kambing ini berada di tempat yang tinggi, berbatu dan jauh dari permukiman manusia, dan mereka tidak mendapat bantuan manusia. Namun mereka tetap dapat melahirkan anak-anak mereka dengan baik.

"Kambing gunung" yang dimaksud di sini tak diragukan lagi adalah kambing gunung yang memiliki tempat tinggal di antara bebatuan, atau di gunung karang. Istilah Ibrani adalah יעל (yâ'êl) dari יעל (ya'al) "gunung karang, pegunungan cadas." Ini menunjukan bahwa kambing ini tinggal di bukit/gunung karang yang tinggi; Mazmur 104:18 menyebutkan bahwa "gunung-gunung tinggi adalah tempat berlindung bagi kambing liar."

Di sini Tuhan membawa Ayub kepada perenungan mengenai seberapa tinggi pengetahuan yang dimilikinya. Dia diperhadapakan dengan peristiwaperistiwa yang terjadi di sekelilingnya, yang berhubungan dengan fakta alam yang bisa dilihat dari pengamatan sederhana. Fakta yang tidak asing bagi Ayub, karena hal itu mudah untuk dilihat. Namun, pertanyaan ini berada di luar kemampuan Ayub untuk menjawabnya. Pada kenyataannya tingkat pengetahuan yang dimiliki oleh Ayub relatif rendah, dia tidak memiliki jawaban atas pertanyaan yang Tuhan berikan.

Pertanyaan ini menjadikan Ayub sadar akan ketidakberdayaanya. Ia didorong masuk dalam kesadaran akan keterabatasanya dihadapan Tuhan. Pengetahuan yang hebat yang dimiliki manusia akan terlihat tidak berarti saat berhadapan dengan Tuhan. Ini juga mendobrak kesombongan diri yang beranjak dari status Ayub sebagai orang yang penuh dengan hikmat menjadi pribadi yang kosong, yang hanya memiliki sedikit pengetahuan.

Meskipun mungkin Ayub mengetahui prinsip-prinsip tatanan alam ini, pada saat yang sama ia 
digiring untuk harus mengakui bahwa tatanan alam semesta, semuanya sepertinya berjalan cukup baik. Semua pertanyaan ini membawa Ayub kepada kebenaran untuk melihat bahwa dunia yang diciptakan oleh Tuhan ini beroperasi dengan tatanan dan kebijaksanaan yang luar biasa. Ayub tidak dapat menyangkal kebijaksanaan dan pemerintahan-Nya terhadap segala sesuatu yang ada di alam semesta hanya karena ada beberapa hal dalam hidup Ayub sendiri yang tidak dapat ia mengerti. Ini juga mendorong Ayub untuk mempercayai Tuhan yang melakukan semua hal dengan sangat baik, tanpa cacat dan cela. Tidak satupun dari apa yang Tuhan kerjakan yang tidak berjalan sempurna.

Pertanyaan Allah mendorong kesadaran dalam diri Ayub akan besarnya pemeliharaan-Nya terhadap semua ciptaan, termasuk dirinya sendiri. Tuhan sanggup memelihara dengan baik kambing gunung yang tidak terjangkau tempatnya oleh manusia untuk memeliharanya, namun Allah sanggup memeliharanya dengan sempurna saat kambing gunung melahirkan anak anaknya, demikian juga Allah sanggup memelihara Ayub dengan baik. Ayub tidak dapat untuk menemukan alasan meragukan pemeliharaan Allah yang sempurna atas ciptaan dan dirinya sendiri.

\section{Analisis Teks Ayub 39:6-7}

Dalam kitab Ayub 39:6-7 dituliskan "Dengan membungkukkan diri mereka melahirkan anakanaknya, dan mengeluarkan isi kandungannya [בליהם (chebleyhem)]. Anak-anaknya menjadi kuat dan besar di padang [ tidak kembali lagi kepada induknya." Kata חבליהם (chebleyhem) artinya mereka mengusir rasa sakit mereka, mengusir kesedihan mereka atau kelahiran anak mereka yang menyebabkan rasa sakit. Dalam kata 7 (bâr) terdapat banyak penafsiran mengenai kata ini, ada yang menerjemahkan sebagai padang gurun, alam terbuka, kebun jagung, atau padang. Arti yang tepat dan biasa dari kata yang digunakan di sini ברân) adalah jagung (gandum). Terdapat perbedaan terjemahan mengenai penggu-
חבליהם חביה (chebleyhem). Dalam Alkitab TB kata ini diterjemahkan dengan kalimat "mengeluarkan isi kandungannya" sedangkan KJV "they cast out their sorrows" (Mereka mengusir kesedihan mereka) sedangkan NIV "their labour pains are ended"(sakit persalinan mereka berakhir).

Gagasan ayat ini tampaknya menekankan bagaimana mereka melakukan persalinan tanpa adanya perhatian dan perlindungan dari para gembala, seperti yang lazim dilakukan para gembala kepada ternak mereka pada musim-musim seperti itu. Mereka melakukannya,dan hanya Tuhan yang menjaga mereka. Waktu mereka berada di padang atau di bebatuan jauh dari tempat tinggal manusia mereka tetap terpelihara. Pokok pikiran yang terkandung dalam semua ini tampaknya, ingin menunjukan tentang perhatian Tuhan yang lembut atas mahluk ciptaanNya. Pada keadaan yang paling berbahaya dan rumit dialami, di sana Tuhan ada untuk menolong, saat manusia tidak dapat menjangkau mereka, dan bahkan tidak dapat mengamati apa yang terjadi terhadap mereka.

Penulis Ayub kemudian meneruskan proses kelahiran kambing dengan pertumbuhan pada ayat בר (bâr). KJV memahami ayat ini dengan "they grow up with corn" (mereka tumbuh dengan jagung), sedangkan NIV "grow strong in the wilds" (tumbuh kuat di alam bebas), dan ESV, NRSV, NETBible menerjemahkan "they grow up in the open" (mereka bertumbuh di tempat terbuka). Herder, Gesenius, Noyes, Umbreit, dan Rosenmuller mengartikan kata ini, "di padang gurun," atau "ladang." Arti yang tepat dan biasa dari kata yang digunakan di sini (bâr) adalah jagung (gandum). (Barnes, 2001).

Idenya bukan karena mereka diberi makan dengan jagung (gandum), yang membutuhkan perawatan manusia. Tetapi mereka dipelihara di bawah pengawasan langsung Tuhan. Bahkan ketika mereka pergi dari induknya mereka dan tidak kembali lagi ke tempat asalnya Tuhan ada memelihara. Di mana mereka dilahirkan, bertumbuh dan pergi Tuhan tetap memelihara. Pemaparan yang detail mengenai kela- 
hiran, dan pertumbuhan dalam ayat ini memberikan penjelasan bahwa Allah memperhatikan dengan seksama segala ciptaan-Nya. Tuhan ada saat anak-anak kambing itu dilahirkan. Ia membantu untuk melahirkan anak-anak mereka.Ia melihat bagaimana anakanak itu bertumbuh, menjadi kuat dan mulai terpisah dari induknya, bahkan tidak kembali lagi kepada sang induk. Tuhan selalu memelihara ciptaan-Nya.

Tuhan melindungi dan terus melindungi mereka. Bahkan ketika mereka mengembara dari tempat asal mereka, terlepas dari sang induk dan tidak berdaya Tuhan memperhatikan mereka. Banyak anak muda membutuhkan perhatian yang cukup lama dari orang dewasa, banyak yang dipelihara dalam jangka waktu yang cukup lama oleh ibu, tapi gagasan di sini tampaknya, bahwa tanggung jawab pemeliharaan anak-anak dari kambing liar, ada sepenuhnya pada Tuhan, dan dilindungi sepenuhnya oleh Tuhan sendiri. Perhatian khusus terhadap pemeliharaan atas hewan-hewan ini tampaknya ditentukan karena tidak ada hewan lain yang mendapat begitu banyak bahaya sejak awal kehidupan mereka seperti anak kambing ini.

Melalui kedua ayat ini Allah mengingatkan Ayub tentang bagaimana Ia menata kelahiran, pertumbuhan dan kedewasaan yang telah ditetapkanNya sebagai tatanan hukum alam. Apakah Ayub terlibat dalam mendesain ini, atau apakah memiliki pengetahuan tentang hal-hal yang terjadi tersebut? Pertanyaan retorika ini bertujuan untuk menyadarkan Ayub keluar dari membanggakan dirinya sendiri, berdasar perbuatan baik yang ia telah lakukan dihadapan Tuhan. Karena semua kebaikan dan kebanggaannya itu tetap menjadikan dia bukan apa-apa di hadapan Tuhan. Allah sendiri menunjukkan kepadanya alasan terbaik mengapa dia harus rendah hati, beranjak dari kesadaran diri, memahami bahwa pengetahuan yang miliki sangatlah terbatas. Ayub hanya memiliki pengetahuan sedikit tentang sifat makhluk-makhlukitu dan dia hanya memiliki sedikit pengaruh terhadap mereka. Karena pada Kenyataannya mereka semua bergantung pada kepada Tuhan. Tidak satupun yang bergantung kepada Ayub.

\section{Analisis Teks Ayub 39:8-9}

Dalam Ayub 39:8-9 tertulis demikian "Siapakah yang mengumbar keledai liar [פרא (pere)], atau siapakah yang membuka tali tambatan keledai jalang [ערוד] (arod)]? Kepadanya telah Kuberikan tanah dataran sebagai tempat kediamannya dan padang masin sebagai tempat tinggalnya." Kata פרא (pere), diterjemahkan keledai liar. Mereka berbeda dari keledai jinak hanya dalam kemerdekaan dan kebebasan mereka, dan karena mereka lebih kuat dan lebih gesit: tapi dalam bentuknya mereka sama (Lihat di Ayub 6:5). Kata ערוד (arod), binatang yang sama dengan keledai, tapi disebut demikian karena dia memiliki kebiasaan sering membuat suara-suara yang aneh. Penyebutan yang berbeda mengisyaratkan hewan ini yang berbeda dari keledai liar seolah-olah hewan ini pernah menjadi tawanan, dan kemudian dibebaskan. Ilustrasi ini berasal dari perasaan yang menghadiri restorasi kebebasan. Kebebasan hewan ini tampaknya sama produktifnya dengan kegembiraan seolah-olah ia adalah seorang tahanan atau budak, dan tiba-tiba dibebaskan. (Barnes, 2001).

Kata yang diterjemahkan dengan keledai liar berasal dari bahasa ibrani פרא (pere). Sifat mereka berbeda dari keledai jinak lainnya hanya dalam kemerdekaan dan kebebasan, dan karena keledai disini lebih kuat dan lebih gesit: tapi dalam bentuknya mereka sama (Lihat di Ayub 6: 5). Barnes (2001) menjelaskan hewan-hewan ini sebagai berikut

Hewan-hewan ini biasanya mendiami bagian kering dan pegunungan padang pasir di Tartary Besar, tapi tidak lebih tinggi dari garis lintang 48 derajat. Mereka bermigrasi, dan tiba di dataran yang luas untuk makan, selama musim panas. Pada musim gugur mereka berkumpul dalam kawanan dengan jumlah ratusan, bahkan ribuan, dan berjalan ke selatan menuju India untuk menikmati istirahat yang hangat selama musim dingin. Tapi mereka lebih biasanya berhenti di Persia, di mana mereka sering dijumpai di pegunungan Casbin; dan sebagian dari mereka tetap tinggal sepanjang tahun. Gerombolan keledai ini juga dikatakan bisa menembus ke bagian selatan India, ke pegunungan Malabar. 
Hewan-hewan ini dahulu ditemukan di Palestina, Syria, Semenanjung Arab, Mesopotamia, Frigia, dan Lyconia, namun jarang ditemui lagi di daerah-daerah tersebut pada masa sekarang. Perilaku mereka mirip dengan kuda liar.

Lebih lanjut diceritakan walaupun mereka berkumpul dalam kawanan hewan-hewan ini memiliki sifat sangat penakut dan waspada. Akan tetapi, sesekali mereka akan berhenti di tengah jalan, sesekali melakukan pendekatan dengan manusia untuk sesaat, dan kemudian melesat dengan kecepatan tinggi.

Untuk memahami bagian ini, maka harus memahami sifat dari keledai liar. Mereka berkeliaran di dataran luas dalam kelompok dan kelompok, dalam jumlah yang besar dan berlari dengan kecepatan yang tidak terkendali oleh kekuatan manusia. Jika menghayati kekuatan dari perbandingan yang dibuat Tuhan di sini, Ia bertanya kepada Ayub apakah dia bisa menaklukkan dan menjinakkan makhluk liar ini dan telah mengalahkan kebebasannya. Dapatkah ia menahannya sebagai tawanan, dan kemudian membebaskannya. Idenya adalah, bahwa itu adalah salah satu ciptaan Tuhan, yang hidup liar, tanpa terikat aturan dan Tuhan telah menetapkan untuk tidak tunduk terhadap perintah manusia.

Bagian ini memiliki tujuan untuk menyadarkan Ayub atas keterbatasan yang dimilikinya. Tidak semua yang ada di dunia ini dapat dia kendalikan. Ada batasan-batasan yang tidak mungkin dapat diatasi oleh dirinya. Dia bukan pengendali segala sesuatu. Dibandingkan dengan Allah, Ayub menjadi tidak berarti dan tidak bedaya.

Hanya Allah saja satu-satunya yang dapat mengendalikan segala sesuatu. Apa yang terbatas un-tuk Ayub adalah suatu hal yang mungkin dilakukan oleh Allah. Kuasa Allah melampaui apa yang bisa dilakukan oleh manusia. Hal ini digambarkan dengan keledai liar yang tidak mampu dijinakan oleh manusia, namun keledai itu berada dalam otoritas Allah sepenuhnya.

\section{Analisis Teks Ayub 39:10-11}

Dalam Ayub 39:10-11 dituliskan "Ia menertawakan keramaian kota, tidak mendengarkan teriak si penggiring; ia menjelajah gunung-gunung padang rumputnya, dan mencari apa saja yang hijau." Artinya, keledai yang digambarkan dalam ayat ini memiliki perilaku yang bertentangan dengan kebiasaan pada umumnya. Kata Ibrani dengan tepat menggunakan istilah שנוג "si penggiring" menggambarkan seorang penindas, dan penggerak ternak. Petunjuk di sini adalah untuk menjelaskan peran pengendali/penjinak hewan, dan maknanya adalah, bahwa keledai ini tidak dapat dijinakan, tapi ia menikmati kebebasan yang tak terbatas. Si keledai tidak terintimidasi oleh kehadiran pengiring. Dia menemukan tempat yang jauh dari kota dengan kebebasan di padang rumput.

Allah sedang memberikan pengajaran kepada Ayub bahwa Ia adalah pengendali segala sesuatu. Keledai liar yang tak terkendali oleh manusia, ia ada dalam kendali Allah. Tidak ada yang tidak dapat dikendalikan oleh Allah. Begitu pula dengan keadaan Ayub saat itu.Semuanya masih dalam kendali Allah sepenuhnya. Allah tidak melupakan Ayub. Keadaan Ayub yang sulit tetap berada dalam kendali Allah yang mahakuasa.

\section{Analisis Teks Ayub 39:12-15}

\section{Dalam Ayub 39:12-15 dituliskan}

Apakah lembu hutan mau takluk kepadamu, atau bermalam dekat palunganmu?Dapatkah engkau memaksa lembu hutan [ראם (re'êm)] mengikuti alur bajak dengan keluan, atau apakah ia akan menyisir tanah lembah mengikuti engkau? Percayakah engkau kepadanya, karena kekuatannya sangat besar? Atau kau serahkankah kepadanya pekerjaanmu yang berat? Apakah engkau menaruh kepercayaan kepadanya, bahwa ia akan membawa pulang hasil tanahmu, dan mengumpulkannya di tempat pengirikan$\mathrm{mu}$ ?

Dalam argumen sebelumnya, Tuhan telah mengimbau Ayub menggunakan penggambaran kepada singa, gagak, kambing gunung, keledai, dan keledai liar. Dimana idenya adalah, bahwa dalam naluri masingmasing hewan ini, ada beberapa bukti kebijaksanaan khusus Allah. Dia sekarang beralih ke jenis lain dari binatang ciptaan-Nya sebagai bukti supremasi dan 
kekuatannya sendiri, dan mengemukakan argumen kekuatan besar dan kemerdekaan-Nya atas hewanhewan, dan faktanya manusia tidak dapat menarik kekuatan besar untuk keperluan lahan pertanian mereka.

Sehubungan dengan hewan yang disebut di sini, ada banyak perbedaan pendapat di antara para penafsir, dan belum menemukan kesepakatan. Jerome mengartikan sebagai "badak;" berdasar terjemah-

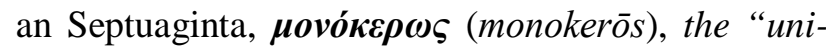
corn". Terjemahan Chaldea dan Siria mempertahankan kata dalam bahasa Ibrani; Gesenius, Herder, Umbreit, dan Noyes, menngartikan sebagai "kerbau; "Schultens, "alticornem." Luther dan Coverdale, memilih "unicorn". Rosenmuller, memilih the "onyx" spesies antelop besar dan galak; Calmet menduga bahwa badak yang sedang dimaksudkan; dan Prof. Robinson, dalam tambahan artikel Calmet menunjukkan bahwa yang dimaksudkan disini adalah kerbau liar. (Barnes, 2001).

Kata yang digunakanditerjemahkan menjadi "unicorn" atau ראם (re'êm) digunakan dalam Kitab Suci hanya di tempat-tempat tertentu, di mana dalam bentuk tunggal atau jamak itu dibuat seragam "unicorn" atau "unicorns". Dengan mengacu pada bagianbagian ini, akan ditemukan bahwa hewan tersebut memiliki karakteristik sebagai berikut:

Pertama, Hewan ini dibedakan karena kekuatannya; lihat Ayub 39:14 dari pasal ini. Bilangan 23:22, "dia (yaitu orang Israel, atau orang Israel), sama seperti kekuatan unicorn" ראם (re'êm). Dalam Bilangan 24: 8 , pernyataan yang sama diulang. Memang benar bahwa kata Ibrani di kedua tempat ini תועפה (tô'âphâh) dapat menunjukkan kecepatan gerak. Tetapi di tempat ini gagasan tentang kekuatan pada dasarnya harus ditekankan. Orang-orang yang disebut oleh Bileam adalah seorang orang yang kuat tinggi atau besar. Jika kata itu berarti kekuatan, sangat tepat untuk membandingkan sejumlah besar orang dengan kekuatan dan ketangkasan seekor binatang liar yang tak dapat ditebak.

Kedua, Hewan ini tidak diberi tugas untuk mengolah tanah, dan ini mengidentifikasi hewan ini tidak dapat dilatih dengan baik. Jadi, saat dikatakan, bahwa dia tidak dapat dijinakkan sehingga dia tetap tinggal seperti lembu di palungan; hal ini membuktikan dia tidak bisa diasosiasikan dengan bajak; bahwa dia tidak dapat dipekerjakan dan dengan aman pergi untuk mengejar pekerjaan di ladang; dan bahwa dia tidak dapat diharapkan sehingga untuk mencoba dengan aman membawa pulang hasil panen melalui bantuannya. Dari semua deklarasi ini, jelas bahwa dia dianggap binatang liar yang tidak bisa dijinakkan, dan itu tidak bisa digunakan di peternakan. Karakteristik ini akan sesuai dengan kijang, onyx, kerbau, badak, atau unicorn.

Ketiga, Kekuatan hewan itu ada di tanduknya. Inilah salah satu karakteristik istimewanya, dan jelas dengan ini ia dirancang untuk dibedakan. Perlu dipahami kata ראם (re'êm) sendiri tidak memiliki referensi ke tanduk, juga tidak ada dalam bahasa Ibrani di mana dugaan hewan yang disebut di sini hanya memiliki satu tanduk. Dimana pun, di dalam Kitab Suci, binatang itu dibicarakan dengan ungkapannya adalah dalam bentuk jamak, "tanduk-tanduk." Satusatunya variasi dari ini, bahkan dalam versi umum, ada dalam Mazmur 92:11 di mana kata tanduk, seperti yang ada dalam versi bahasa Inggris, tidak diungkapkan. Memang ada, dalam bagian ini, ada beberapa kiasan yang jelas pada tanduk hewan ini, tapi semua kekuatan perbandingan akan dipertahankan jika kata yang dimasukkan ada dalam jumlah jamak. Namun tanduk atau kata ראם (re'êm) tidak diragukan lagi, acuan utamanya adalah kekuatan, dan instrumen serangan dan pembelaan.

Kelima, Ada keagungan atau martabat istimewa di tanduk binatang ini yang menarik perhatian, dan itu menjadikannya simbol kekuasaan dan otoritas. Seperti dalam Mazmur 92:11 di mana rujukan dari ayat ini tampaknya adalah otoritas raja atau kerajaan. Tanduknya adalah simbol dari kekuasaan.

Empat hal ini semua adalah karakteristik hewan bertanduk yang disebut dalam Kitab Suci: hewan dibedakan karena kekuatannya, binatang ini tidak diberi tugas untuk mengolah lahan, kekuatan hewan itu ada di tanduknya,keagungan atau martabat 
istimewa di tanduk binatang ini yang menarik perhatian, dan itu menjadikannya simbol kekuasaan dan otoritas.

Hewan yang disebut dalam teks ini sebagai salah satu hewan dengan kekuatan yang sangat besar, namun di luar kemampuan manusia untuk membuatnya berguna bagi pekerjaan di ladang. Dilengkapi dengan struktur fisik dan kekuatannya yang besar, untuk dipekerjakan seperti lembu atau keledai dalam usaha pertanian; Tapi, dari disposisi yang tidak terkendali, tidak dapat ditundukkan oleh manusia untuk tujuan ini.

Referensi yang dimaksudkan oleh Yang Mahakuasa untuk mengingatkan Ayub agar memiliki kerendahan hati dihadapan kekuatan Penciptanya. Pelajaran kerendahan hati tersirat dengan pemikiran jika manusia tidak mampu mengikat dan memanfaatkan binatang seperti ראם (re'êm) bagi pekerjaan ladangnya, bagaimana dia bisa bersaing dengan Penciptanya? Jika tidak bisa memerintah makhluk ciptaan belaka, betapa tidak mungkin ia mempertanyakan urusan dari Penciptanya! Beberapa hewan tampaknya akan sangat berguna dan menjadi lebih bermanfaat bagi kepentingan manusia, namun pada kenyataannya manusia tidak dapat mengendalikannya. Otoritas manusia tidak mampu mengalahkan dan mengedalikan kekuatan binatang ini. Dia tidak memiliki pengetahuan dan penguasaan atas semua ciptaan. Setidaknya ini cukup untuk membuat Ayub sadar diri dengan keberadaan Allah.

Allahlah pengendali dari ראם (re'êm).Dan Ia juga pengendali dari kehidupan Ayub. Tidak ada satu pun di dunia yang sulit untuk Allah taklukan. Setiap masalah yang Ayub alammi pun dapat dengan mudah Allah taklukan. Sekalipun tidak ada satu manusia yang dapat menaklukannya,namun bagi Allah tidak ada yang mustahil untuk menaklukan masalah yang menimpa Ayub

\section{Implikasi}

Dari analisis di atas ada dua implikasi yaitu implikasi teologi dan implikasi praktis.

\section{Teologis}

Sepintas semua jawaban yang Allah berikan kepada Ayub tidak memiliki kaitan dengan apa yang Ayub alami. Tidak ada hubungannya antara hewanhewan dan penderitaan Ayub. Pertanyaan-pertanyaan Ayub seputar penderitaannya masih belum terjawab (Biji, 2000, p. 77). Namun Allah tahu bahwa itu adalah saat yang tepat untuk berbicara dengan Ayub.

Pertanyaan-pertanyaan retorika yang Allah berikan kepada Ayub, sengaja Allah ajukan untuk menggugah kesadaran Ayub akan kebesaran dari Tuhan. Dari penggunaan jenis-jenis hewan yang Allah ajukan kepada Ayub, ditemukan bahwa setiap hewan memiliki peranan dalam menjelaskan sifat Allah yang tidak terbatas dan tidak terkalahkan. Ayub dibuat tidak berdaya dengan keberadaan hewan-hewan tersebut. Pada akhirnya Ayub digiring untuk sadar akan ketidaktahuannya akan cara-cara hidup para hewan (Guthrie, 2006, p. 107). Ayub juga disadarkan akan pemeliharaan Allah yang luar biasa atas seluruh ciptaan, termasuk dengan pribadi Ayub.

Di sini Tuhan membawa Ayub kepada perenungan mengenai seberapa tinggi pengetahuan yang dimilikinya. Dia diperhadapakan dengan peristiwaperistiwa yang terjadi di sekelilingnya, yang berhubungan dengan fakta alam yang bisa dilihat dari pengamatan sederhana. Fakta yang tidak asing bagi Ayub, kerena hal itu mudah untuk dilihat. Namun, Pertanyaan ini berada di luar kemampuan Ayub untuk menjawabnya. Pada kenyataannya tingkat pengetahuan yang dimiliki oleh Ayub relatif rendah, dia tidak memiliki jawaban atas pertanyaan yang Tuhan berikan (Ammerman \& Maritim, 1979, p. 65). Allah mengajukan beberapa pertanyaan yang menunjukan bahwa Dia besar dan Ayub kecil.

Meskipun Ayub tidak mengetahui prinsipprinsip tatanan alam ini, pada saat yang sama ia digiring untuk harus mengakui bahwa tatanan alam semesta, semuanya sepertinya berjalan cukup baik. Semua pertanyaan ini membawa Ayub kepada kebenaran untuk melihat bahwa dunia yang diciptakan oleh Tuhan ini beroperasi dengan tatanan dan kebijaksanaan Tuhan yang luar biasa. Ayub tidak dapat 
menyangkal kebijaksanaan dan pemerintahan-Nya terhadap segala sesuatu yang ada di alam semesta hanya karena ada beberapa hal dalam hidup Ayub sendiri yang tidak dapat Ayub mengerti. Ini juga mendorong Ayub untuk mempercayai Tuhan yang melakukan semua hal dengan sangat baik, tanpa cacat dan cela. Tidak satupun dari apa yang Tuhan kerjakan yang tidak berjalan sempurna.

Secara teologis Ayub 39:4-15 sedang memaparkan tentang sifat-sifat Allah. Sifat pertama yang diusung adalah Allah yang Maha Tahu. Sifat ini dijelaskan dengan bagaimana Dia memperhatikan dengan seksama kehidupan hewan-hewan yang luput dari pengertian dan perhatian manusia. Sifat kedua adalah Allah yang maha kasih. Ini terlihat jelas dari bagaimana Allah terlibat langsung dalam kelahiran dan pertumbuhan kambing gunung, dan bagaimana Allah memberikan tanah lapang kepada keledai liar. Jika Allah sanggup menyatakan kasih-Nya kepada ciptaan yang disebutkan, maka Dia juga sanggup menunjukan kasih-Nya kepada Ayub. Sifat ketiga adalah Allah yang maha kuasa. Kemahakuasaan Allah tampak dengan kuasanya atas kambing gunung, keledai liar, dan unicorn/lembu hutan. Di mana hewan-hewan tersebut pada kenyataanya tidak dapat dijinakan oleh manusia, tetapi semuanya adalah ciptaan dan dalam kendali Allah. Ini juga menjelaskan bahwa Allah berkuasa atas apa yang menimpa Ayub.

\section{Praktis}

Jawaban retorika Tuhan atas pertanyaan Ayub yang terdapat dalam Ayub 39: 4-15, pada dasarnya seolah-olah tidak menjawab penderitaan yang sedang dialami oleh Ayub. Tidak ada keterkaitan antara semua jenis hewan yang disebutkan dengan pengalaman penderitaan Ayub. Namun demikian jawaban Tuhan ini memberikan perenungan yang mendalam tentang bagaimana seharusnya manusia bersikap di hadapan Tuhan. Adapun beberapa sikap yang harus dimiliki manusia di hadapan Tuhan adalah sebagi berikut:
Pertama, Manusia Harus Memiliki Sikap Rendah Hati. Kerendahan hati adalah sikap yang menilai diri sendiri secara wajar dan tidak berlebihan. Kisah Ayub memberikan pembelajaran berharga tentang nilai dari kerendahan hati. Ayub memang dinyatakan sebagai orang yang saleh dan jujur, namun pernyataan ini justru membawa Ayub mempertanyakan keadilan Tuhan terhadap dirinya.Ia melihat kejadian yang menimpa dirinya adalah wujud ketidakadilan Tuhan. Pertanyaan-pertayaan retoris Tuhan kepada Ayub mengenai berbagai macam hewan sebenarnya mendorong Ayub melihat kebesaran Tuhan dan betapa kecilnya dirinya. Ketidakmampuan Ayub dalam menjawab pertanyaan Tuhan, setidaknya menyadarkan dia, bahwa ia terbatas, sekalipun ia memiliki predikat saleh dan jujur. Alih-alih mempertanyakan tindakan Tuhan, sebaiknya manusia lebih menanyakan kepada diri sendiri, apa yang harus dilakukan ketika mengalami penderitaan. Dengan tetap percaya bahwa segala sesuatu yang terjadi berada dalam kendali Tuhan.

Kedua, Manusia tidak dapat mengukur keadilan Tuhan berdasarkan apa yang dia alami. Seringkali orang pendapat bahwa orang benar pasti diluputkan dari penderitaan. Berberapa orang berpandangan penderitaan terjadi karena dosa, dan itulah keadilan Tuhan. Jika menyimak kisah Ayub, maka dapat melihat bahwa peristiwa yang Ayub alami membatalkan pandangan tersebut. Manusia tidak dapat menilai keadilan Tuhan berdasarkan apa yang dialaminya. Hanya karena dia merasa saleh, kemudian menderita lalu mengambil kesimpulan bahwa Allah tidak adil. Pemikiran seperti ini adalah pemikiran yang sempit. Orang percaya harus yakin sekalipun ia mengalami penderitaan, Tuhan tetap adil. Keadilan Tuhan tidak dipengaruhi apakahIa mendapatkan hal yang baik atau yang buruk.

Ketiga, Manusia harus mengakui keterbatasannya dihadapan tuhan. Tidak ada manusia yang hidup tanpa keterbatasan. Selalu ada kelebihan dan keterbatasan yang dimiliki oleh semua manusia. Tidak satu pun manusia di dunia yang lahir sempurna. Keterbatasan yang menjadikan manusia tidak dapat se- 
penuhnya memahami akan rencana Tuhan. Ayub 39: 4:15 mengajarkan bahwa manusia sangatlah mustahil untuk berpekara dengan Tuhan. Pertanyaan-pertanyaan yang Tuhan berikan kepada Ayub menyadarkan dia akan keterbatasan memahami segala hikmat dan pemeliharaan Tuhan atas segala ciptaan. Ini mengajarkan bahwa sekalipun manusia tidak memahami akan rencana Tuhan dalam hidupnya, ia harus tetap percaya dan jangan pernah meragukan Tuhan.

\section{KESIMPULAN}

Seringkali dalam hidup saat pencobaan menerpa kehidupan, orang menanyakan kenapa hal buruk dapat terjadi dalam dirinya. Di tengah kesulitan hidup yang semakin menghimpit manusia mempertanyakan dimanakah kuasa Tuhan yang sanggup menolong dirinya. Keluh kesah yang disampaikan dalam doa ataupun perbincangan dengan orang lain selalu berusaha menemukan jawaban akan kuasa $\mathrm{Tu}$ han atas apa yang dialami.

Saat Tuhan terkesan diam dan seolah-olah tidak menjawab pergumulan, perlu dipahami bahwa hal itu tidaklah membuktikan bahwa Allah tidak peduli terhadap umat-Nya. Terkadang perlu sejenak untuk merenungkan akan karya Tuhan yang besar akan dunia ini, tentang alam semesta yang bergerak dengan baik, hewan-hewan buas yang terpelihara, dan bagaimana semua itu tertata tanpa campur ta-

\section{DAFTAR RUJUKAN}

Ammerman, L., \& Maritim, J. 1979. Melihat ke dalam Perjanjian Lama. Bandung: Kalam Hidup.

Baker, D. L. 1992. Mari Mengenal Perjanjian Lama. Jakarta: BPK Gunung Mulia.

Barnes, A. 2001. Albert Barnes' Notes on the Whole Bible. Retrieved Nopember 2, 2017, from StudyLight.org: https://www.studylight.org /com /commentaries/bnb/job-39.html

Biji, C. 2000. Ayub Sang Konglomerat. Jakarta: Yayasan Komunikasi Bina Kasih. ngan manusia, itu menunjukan bahwa Tuhan tidak pernah berdiam diri.

Jika hewan buas dipelihara oleh Tuhan dengan sempurna tanpa pertolongan manusia, demikian juga umat-Nya lebih lagi akan Tuhan pelihara. Pertanyaan Tuhan kepada Ayub berkenaan hewanhewan buas yang dipelihara oleh Tuhan -sekalipun seolah-oleh tidak ada kaitannya dengan apa yang dialaminya - telah menyadarkan Ayub akan keterbatasan dirinya, dan kebesaran Tuhan atas semua ciptaan.

Demikian pula dengan orang percaya saat ini. Peristiwa yang dialami Ayub memberikan pelajaran berharga bagi orang percaya. Umat Tuhan perlu sadar bahwa dalam apa yang Allah ijikan terjadi terdapat rencana besar yang tidak terselami oleh pemikiran manusia. "diam"nya Allah bukan berarti Dia tidak peduli atau tidak sanggup menolong orang percaya, melainkan disinilah diperlukan iman untuk mempercayai Allah sampai segala sesuatunya menjadi nyata bahawa Ia mengijinkan segala sesuatu terjadi demi kebaikan umat-Nya. Jika Dia sanggup memelihara dengan baik hewan buas yang tidak terjangkau tempatnya, maka Allah juga sanggup memelihara umat-Nya dengan baik. Manusia tidak dapat meragukan pemeliharaan Allah yang sempurna atas ciptaan dan dirinya sendiri.

Davidson, F. 2006. Tafsir Alkitab Masa Kini 2: Ayub-Maleakhi. Jakarta: Yayasan Komunikasi Bina Kasih/OMF.

Guthrie, D. 2006. Tafsiran Masa Kini 2: Ayub-Maleakhi. Jakarta: Yayasan Komunikasi Bina Kasih/OMF.

Harlow, R. 1983. Job Had A Problem. Canada: Everyday Publicaton INC.

Maryono, P. 2017. Analisis Retoris. Yogjakarta: Andi.

Stevanus, K. 2018. Analisis Pertanyaan Retorika dalam Ayub 40:1-28. Dunamis: Jurnal Teologi dan Pendidikan Kristiani, 2 (2): 119-135. 
Subagyo, A. B. 2004. Pengantar Riset Kualitatif dan Kuantitatif. Bandung: Kalam Hidup.

Tolanda, I., \& Maiaweng, P. 2011. Kedaulatan Allah Atas Iblis Berdasarkan Kitab Ayub
Pasal 1 dan 2 Serta Relevansinya Dalam Kehidupan Orang Percaya. Jurnal Jaffray, 9 (2): 53-89. 